\section{Scientists' attitude to weapons}

SIR-Nature is an influential journal among professional scientists, and for this reason I would like to see some dialogue about the morality of weapons science in your Correspondence columns. This is an issue of professional importance to some of your readers (those in the weapons industry) and of life or death importance to all.

We must ask ourselves how to stop the military madness which infects economies, societies and science. For centuries, scientists and engineers have been employed by governments to move troops across rough terrain or maintain the health of troops in hostile environments. These innocuous military advances have produced many benefits for our society such as air transport and tropical medicine. But within the lifetime of many of your readers, science has evolved as the agent of death for the innocent. Unlike our ancestors' inventions, nuclear, chemical and biological weapons are designed for genocide. The superpowers have manipulated scientists to do their bidding by appealing to patriotism, paranoia and purse-strings. I believe these scientists and engineers must be accountable for their actions.

No president, secretary, dictator or monarch knows how to build a nuclear weapon or a recombinant pathogen. They only know how to manipulate the people who have the know-how. Hitler did not design a gas chamber, a patriotic engineer did the dirty work. V2 rockets sprang from the minds of scientists doing their duty for their country. Even some members of the medical profession, in spite of the hippocratic oath, tortured and murdered civilians in the paranoia of Nazi Germany. History can teach us only what we will allow ourselves to learn and learning begins with tough questions. Who made the chemical weapons that killed civilians along the Iran-Iraq border recently? Are they pleased with the results? Do these chemists condemn their historical counterparts or emulate them under a different guise? Who are the engineers who develop armaments which so effectively kill 'rebels' all over the world (on both 'sides')? Do they defend their actions by claiming "I only build them I don't use them!"? Will I be a victim of my fellow scientists' creation? Do the scientists and engineers who develop these weapons expect their respective governments to shoulder the moral responsibility?

As scientists and human beings, we have an obligation to question our motives and make moral decisions about our involvement in the military-industrial complex. The minds and money wasted on military applications are staggering and could be put to constructive use. It is too late to keep the secrets of mass destruction from falling into the wrong hands, but it is not too late to teach our graduate students and peers that it is wrong to research and develop more efficient means to murder and destroy. Perhaps it is time that the scientific community organized to oppose those forces that cause us to be technoaccomplices to murder.

Department of Biochemistry and Molecular Biology,

Louisiana State University Medical Center,

1901 Perdido Street, New Orleans, Louisiana 70112-1393, USA

\section{Bad theology}

SIR-It was good to be reminded by Euan Nisbet that the problem with so-called 'creationism' is not just that it is bad science, but also that it is bad theology (Nature 334, 575; 1988). Nisbet's review also underlines the fact, sometimes lost in the rather murky and polarized 'creation/ evolution' debate, that the great majority of scientists who are also Christians do their science very happily within the paradigm of evolution. The fact that we are a rather 'silent' majority, should not detract from the historical evidence showing not only that evolution was accepted remarkably quickly by most church leaders of the last century', but also that many well-known Christians at the time were active proponents of Darwin's theory².

The creationists' insistence that the Bible should be read as a kind of scientific textbook is an idea that was heavily criticized by the leading figures of the seventeenth century scientific revolution, many of whom were committed Christians. John Wilkins, a founder member of the Royal Society, wrote over 300 years ago ${ }^{3}$ :

"It were happy for us, if we could exempt Scripture from Philosophical controversies: If we could be content to let it be perfect for that end unto which it was intended, for a rule of our Faith and Obedience, and not stretch it also to be a Judge of such Natural Trusts as are to be found out by our own Industry and Experience".

Similar components may be found in the writings of Kepler, Galileo and Boyle, and indeed this view has been the mainstream Christian view down the centuries.

\section{Imperial Cancer Research Fund}

Denis R. Alexander

Laboratories,

PO Box No. 123,

Lincoln's Inn Fields,

London WC2A $3 P X, U K$

1. Chadwick, $O$. in The Victorian Church, Part 2, 23-35 (Black, London).

2. Livingstone, D. N. Darwin's Forgotten Defenders (Eerdmans/Scottish Academic, Edinburgh, 1987)

. Hooykaas, R. Religion and the Rise of Modern Science. 116 (Scottish Academic, Edinburgh, 1972).

\section{Dual-role Hanford}

SIR-The leading article "Nuclear togetherness" (Nature 334, 551; 1988) seems to ignore the fact that the Hanford nuclear reactor has, for more than 20 years, produced both plutonium for military purposes and electricity for the Washington public power supply system. Thus the US Department of Energy's proposal to make the modular high temperature gascooled reactor (HTGR) dual-purpose is entirely consistent with well-established practice.

The modular HTGR achieves a level of passive safety that far exceeds that of any existing commercial reactor. As such it offers an opportunity for a new era of nuclear energy based on reactors for which the possibility of a Three-Mile Island, let alone a Chernobyl, is practically nil.

The Department of Energy, and Senator McClure, rather than being chided, should be congratulated for having proposed a practical path for developing this super-safe reactor technology at a time when commercial nuclear energy development is almost at a standstill in the United States.

Alvin M. Weinberg

Institute for Energy Analysis,

Oak Ridge Associated Universities,

PO Box 17, Oak Ridge,

Tennessee 37831-0117, USA

\section{Price of freedom}

SIR-The leading article by John Maddox, "What price academic freedom?" (Nature $334,377 ; 1988)$ is a timely eye-opener to academics anywhere. The ultimate price is of course dismissal. Many of us at the University of Malta were in fact dismissed in 1978. It is not quite correct to say that the university gave in to the government of the day. The comparison of academics with farmers does not do justice to farmers. Firmness, as any farmer can tell academics, can stop academic rot.

W. H. BANNISTER

Department of Biomedical Sciences,

University of Malta,

Msida, Malta

\section{Nothing signifying}

SIR-Following the recent correspondence in Nature, I get the impression, that there must be something about homoeopathy. I don't believe that no-more existent molecules can leave an imprint in water. But isn't it striking, how a nonexistent phenomenon can leave an imprint in the scientific discussion?

KaRL O. RothHAUPT

Max-Planck-Institut fur Limnologie,

Abteilung Ökophysiologie,

Postfach 165

D-2320 Plön, FRG 